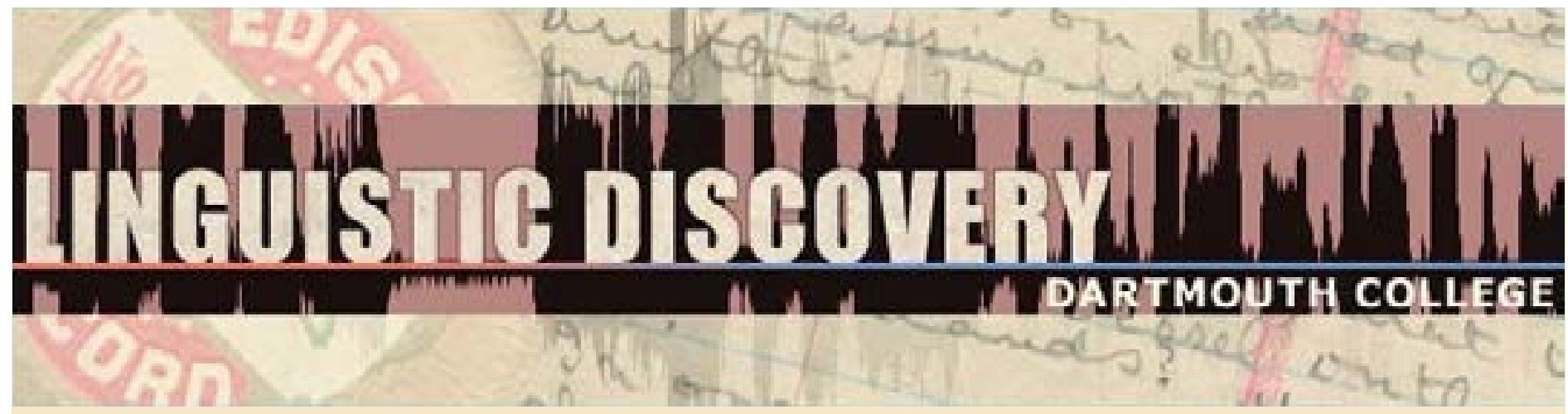

Volume 1

Issue 1 2002
On Some Control Structures in Hellenistic Greek: A Comparison with Classical and Modern Greek

Brian D. Joseph

The Ohio State University

doi: 10.1349/PS1.1537-0852.A.61

url: http://journals.dartmouth.edu/cgi-bin/WebObjects/ Journals.woa/1/xmlpage/1/article/61
Linguistic Discovery

Published by the Dartmouth College Library Copyright to this article is held by the authors. ISSN 1537-0852 linguistic-discovery.dartmouth.edu 


\title{
On Some Control Structures in Hellenistic Greek: A Comparison with Classical and Modern Greek*
}

\author{
Brian D. Joseph \\ The Ohio State University
}

\begin{abstract}
Control Structures in Ancient Greek typically involved infinitival complementation while in Modern Greek, finite complementation is the rule. Hellenistic Greek provides an interesting "way-station" between these two types of complementation, inasmuch as it is both chronologically and structurally transitional. In this contribution to the historical syntax of Greek, an analysis is offered of control structures in Hellenistic Greek, tracing the transition from the Ancient Greek type to the Modern Greek type. Based on the evidence of these three stages of Greek and the developments that the language shows with regard to innovations in the form and properties of control structures, an argument is put forth in support of the view that control is not a purely syntactic phenomenon but rather derives from the lexical semantics of the predicates involved.
\end{abstract}

\section{Introduction}

The proper analysis of control structures is a much debated aspect of linguistic theory, whether "control" is taken in a narrow sense to refer to a nonfreely arrived at, i.e. controlled, interpretation of an empty category, and in particular a missing subject, or in broader terms to take in the interpretation of missing objects as well or even of any nonfreely selected anaphor. At the risk of oversimplification of the issues, the different positions on control can be roughly characterized as viewing control on the one hand as a syntactic phenomenon, involving the interpretation of the [+anaphoric, +pronominal] syntactic element designated as PRO (e.g. by Chomsky 1981 and others generally working in a Government and Binding approach to syntax), ${ }^{1}$ and on the other hand as a property that derives from the lexical semantics of the particular verb or predicate involved (e.g. Comrie 1985, Farkas 1988, Ladusaw \& Dowty 1988, and more recently, Culicover \& Jackendoff 2001).

For the most part, the justification for one or the other position has come from synchronic data and analyses, generally drawing on facts from modern languages, yet some insights into the nature of control can be gleaned as well from historical syntax, both from the examination of control in early stages of Greek, especially Greek of the Hellenistic period, covering some 700 years from the 3rd century BC to roughly the 4th century $\mathrm{AD}$, and from the examination of changes in Greek control structures that first emerged within the span of Hellenistic Greek and are now evident from a

\footnotetext{
"I would like to thank Pauline Welby for her assistance with some of the research that made this contribution possible. The comments of two anonymous reviewers have improved the paper considerably, especially on technical matters and references pertaining to GB theory.

${ }^{1}$ Although I am treating Chomsky (1981) as more or less the "standard" view of control within GB theory, there are certainly other approaches that have been taken within that very framework; for instance, Bouchard (1984) attempts to reduce the distribution of PRO to Case Theory, a view taken as well by, e.g., Koster (1984), among others. More recently, Hornstein (1999), working from the perspective of the Minimalist Program, has argued that certain instances of control can be reduced to syntactic movement. Culicover \& Jackendoff (2001) offer interesting counter-arguments to Hornstein's proposal, and provide as well a good summary of the issues; note also the papers in Larson et al. (1992), where the range of viewpoints on control becomes especially evident.
} 
comparison of Greek of this era with Greek of other periods, especially Classical Greek of the 5th century BC and Modern Greek. Thus in this paper, the nature of control in Hellenistic Greek and Greek in general is studied with an eye to developing arguments from historical syntax concerning the analysis of these important structures.

\section{Control Structures in Hellenistic Greek}

At first glance, control structures in Hellenistic Greek seem rather unexceptional, especially when viewed from the perspective of a theory of control, such as Government and Binding theory, that has been developed mostly on the basis, at the outset at least, of languages like English and French. That is, the relevant control structures, in which an argument of a main-clause predicate governs the interpretation of an unexpressed argument of a subordinate-clause verb, look very much in Hellenistic Greek like the parallel cases in English, in particular in having an infinitive as the complement verb, as a comparison of the Greek versions in (1) and (2) and their corresponding English translations shows: ${ }^{2}$

$\begin{array}{llllll}\text { ērnēsato } & \text { legesthai } & \text { huios } & \text { thugatros } & \text { Pharaō } & \text { (Heb. 11:24) } \\ \text { refused/3SG } & \text { call/PASS.INF } & \text { son/NOM } & \text { daughter/GEN } & \text { Pharaoh/GEN } & \\ \text { 'He refused to be called the son of Pharaoh's daughter.' } & \end{array}$

(2) ouk eimi aksios to hupodëma tōn podōn lusai (Acts 13.25) not am/1SG worthy/NOM the-sandal/ACC the-feet/GEN loosen/INF 'I am not worthy to loosen the sandal of (his) feet.'

Similar parallels with comparable English constructions are found with verbs such as arkhomai 'begin', epithumeō 'desire', tolmaō 'dare', and, in "like-subject" cases where the main-clause subject and the complement subject are identical, thelo 'want', as well as in purpose constructions with verbs of motion, as shown by the Greek and the corresponding English translation in (3):

\section{(3) ēlthomen proskunēsai autōi (Matt. 2.2) \\ came/1PL pay-homage/INF him/DAT \\ 'We have come to pay homage to him.'}

These constructions all seem quite parallel in form to their English counterparts and thus would presumably be represented syntactically as having PRO as subject of the infinitive, just as is the usual representation in GB theory for the parallel English sentences. ${ }^{3}$ Thus (1) through (3) could be represented as in (4):

\footnotetext{
${ }^{2}$ All non-Modern forms and sentences for Greek are given in transliteration based on standard Greek orthography (though without accents), even though this orthography really reflects only Classical Greek pronunciation, not that in later stages of the language. Still, since the non-Modern forms are all known from written textual attestations, it seems best to present them in a rendering of their spelled form, even if it is not an adequate representation of the pronunciation at all stages after the 5 th century BC. Modern Greek forms are given in a roughly phonemic transcription.

${ }^{3}$ Such an analysis is explicitly argued for in Philippaki-Warburton \& Catsimali (1997), where some adjustments in the conceptualization of PRO for a language like Greek (both Ancient and Modern) are proposed as well.
} 
(4a) [ ērnēsato [PRO legesthai huios ...] ]

(4b) [ ouk eimi aksios [PRO to hupodēma tēn podōn lusai ] ]

(4c) [' lthomen [PRO proskunēsai autōi ] ]

However, while verbs such as arkhomai, epithume $\bar{o}$, tolma $\bar{o}$, like-subject thelo, and others (see below) occur exclusively with infinitival complementation in Hellenistic Greek of the New Testament, some verbs and some constructions show a variant in complement-type that might point to a different syntactic representation; in particular, as part of an on-going development within Hellenistic Greek that continued on into and through Medieval Greek, reaching full generalization to all complement structures by early Modern Greek, complement clauses that are finite (i.e., with agreement features) and are introduced by the conjunction hína (in its later form, $n a$ ) could substitute for the infinitive. ${ }^{4}$ Some examples are given in (5), contrasting with infinitival constructions in (2) and (3) above:

$\begin{array}{lllllll}\text { ouk } & \text { eimi } & \text { egō } & \text { aksios } & \text { hina } & \text { lusō } & \text { autou } \\ \text { not } & \text { am/1SG } & \text { I/NOM } & \text { worthy/NOM } & \text { CONJN } & \text { loosen/1SG } & \text { his }\end{array}$

ton himanta tou hupodēmatos

(Jn. 1:27)

the-strap/ACC the-sandal/GEN

'I am not worthy to loosen his sandal-strap.'

(literally: 'I am not worthy that I loosen his sandal-strap.')

(5b) hupagei eis to mnēmeion hina klausēi ekei (Jn. 11:31)

goes/3SG to the-tomb/ACC CONJN cry/3SG there

'She is going to the tomb to cry there.'

(literally: 'She is going to the tomb (in order) that she cry there.')

Moreover, in later Hellenistic Greek, other verbs that had been exclusively infinitival in New Testament Greek, especially thélō 'want', in its like-subject uses, as in (6a), came to occur with finite complements, as in (6b): ${ }^{5}$

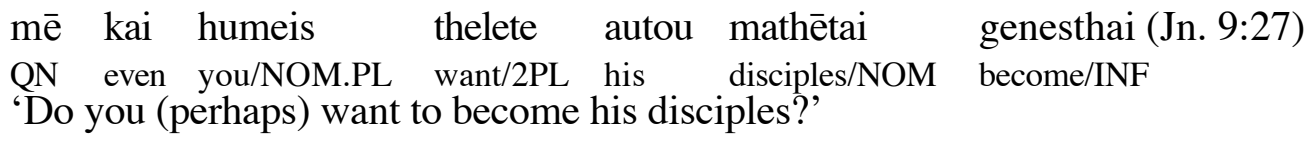

\footnotetext{
${ }^{4}$ See Joseph (1978/1990) and (1983) for discussion of and references on this infinitive-replacement process.

${ }^{5}$ While a subjunctive verb, i.e. phoneuōsin, might well be expected in the complement of (6b), based on Classical Greek usage, an apparent indicative form ocurrs instead; most likely, given the somewhat late date of the text (c. 350AD, according to the received opinion), the use of an indicative here is testimony to the effacing of the subjunctive/indicative distinction that began early in the PostClassical period due to the effects of sound change and various levellings.
} 


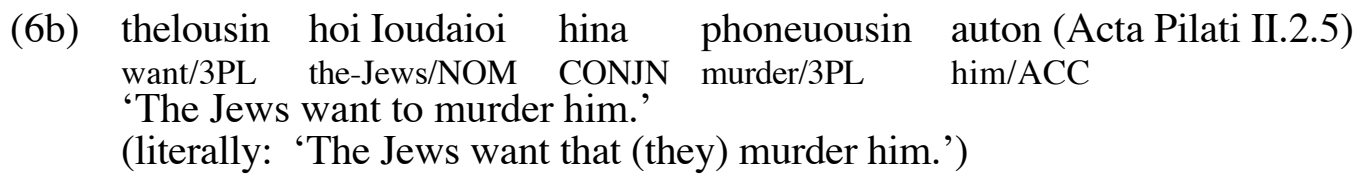

One important observation at this point is that Hellenistic Greek, as indeed all known stages of Greek have been, was a pro-Drop language, and thus allowed finite clauses without an overtly expressed subject; several of the main-clause verbs in the examples above show this aspect of Greek syntax clearly, for no overt subject, whether a noun or a pronoun, appears with the main verbs in (1), (2), (3), or (5b), for instance, and yet these sentences are well-formed. Thus Hellenistic Greek, in addition to the empty category PRO as the subject of infinitivals, would also, within a GB approach to syntax, have had a pro subject as well, representing the (potentially) empty subject of finite verbs. This observation raises the question of what the empty category is in the complement clause of the innovative infinitive-less sentences of the type found in (6b); in particular, is the subject of the finite complement verb a controlled empty category, that is, PRO occurring with a finite verb, or is it simply pro, the result of Subject pro-Drop in the complement clause? If the former, then some adjustment in the assumptions about PRO must be made, and if the latter, then some mechanism may be needed to assure like-subject interpretations.

\section{PRO or pro in Greek Control Structures?}

Relevant to the question of whether finite complement structures in control contexts, such as (6b) with thelo 'want', have a controlled PRO or instead a pro as the lower clause subject is the fact that the complement of thelo need not have a subject that is identical with the main clause subject. This observation holds both for infinitival complements, in which case Greek shows the "accusative with infinitive" (AI) complementation, and for the innovative finite complements; both types could even occur conjoined, as indicated in (7), where the first conjunct has accusative casemarking on the subject of the infinitive while the second conjunct has the innovative finite complementation with no accusative subject: ${ }^{6}$

\footnotetext{
${ }^{6} \mathrm{AI}$ complementation may involve Subject-to-Object Raising, at least in some cases, though other plausible analyses have been offered. Miller (1974), for instance, argues that it has accusative simply as part of the marking of a complement subject (since, for instance, verbs that take genitive objects, such as deomai 'beg' can take AI complementation), and Chaski (1988) posits an abstract complementizer (analogous to for in English but phonologically empty) that governs the appearance of accusative case. See also Philippaki-Warburton \& Catsimali $(1990,1997)$ for a reconsideration of AI complementation in Ancient Greek. Nothing in this paper hinges crucially on the analysis of this type of complementation, though I am inclined to see it as involving Raising at least for some verbs. An argument for Raising from the diachronic development of this type is given in Joseph (1992), based on the fact that there is an apparent noninfinitival continuation of AI that has an accusative and a full finite complement clause, though the analysis of that type in Modern Greek is admittedly controversial (see Joseph 1978/1990: 252ff., notes G,H,L,N and the Appendix, for references and discussion).
} 


$\begin{array}{llllllll}\text { thelō } & \text { de } & \text { pantas } & \text { humas } & \text { lalein } & \text { glōssais } & \text { mallon } & \text { de } \\ \text { want/1SG } & \text { but } & \text { all/ACC } & \text { you/ACC } & \text { speak/INF } & \text { tongues/DAT } & \text { more } & \text { but }\end{array}$

hina prophēteuēte

(1Cor. 14:5)

CONJN prophesy/2PL.SUBJNC

'I want you all to speak in tongues or rather to prophesy.'

(literally: "I want you all to speak in tongues but even more that you prophesy.')

In the first conjunct, there is an overt subject (humas) with the complement verb whereas in the second conjunct, there is a finite second person plural subjunctive verb but no overt subject. Since that subject would not be in a position to be controlled by a higher-clause nominal, but also because there is no particular emphasis on the complement clause subject, the most reasonable assumption concerning the missing subject with prophèteuēte is that pro-Drop is responsible. This analysis in turn suggests that a controlled (i.e. like-subject) finite complement subject, as in (6b), is also missing due to pro-Drop.

That is, assuming that pro-Drop is at work in the complement clause of (6b) means that one can generalize over (7) and (6b) and posit pro-Drop as the cause of the absence of the subject of finite complement clauses in general. The fact that thelo can have either a complement with a like-subject, as in (6), or one with an unlike subject, as in (7), is consistent with this approach, for one need not say anything syntactic about the control properties of main verb thelō. The meaning of thelo as a main verb is such that it allows complements with subjects that are identical to the main clause subject as well as those with subjects that are not identical. Then one need only posit that thelo innovatively simply takes as its complement a full finite clause, with any sort of subject, and pro-Drop does the rest; the like-subject interpretation is a function of the complement clause having a like-subject in underlying structure, a like-subject that (generally) does not surface due to pro-Drop, and the unlike-subject interpretation similarly is a function of the complement clause having an unlike-subject in underlying structure, a subject which, when pronominal, also does not (generally) surface, again due to the requirements of pro-Drop.

There may be additional evidence that pro-Drop is at work from a consideration of the differences between (6b), which shows that the subordinate clause subject in the innovative finite complementation can be empty, and seemingly parallel sentences in which a complement subject appears overtly. Caution is necessary here, for the best available apparent example of that sort ${ }^{7}$, from the Epistles of Ignatius from the early 2nd century $\mathrm{AD}$, as given in (8), may be subject to an alternative interpretation; thus the Greek and a word-by-word gloss is given first, and a translation and ultimate interpretation vis-à-vis control follow after some discussion:

$$
\begin{array}{llllll}
\text { thelēsate } & \text { hina } & \text { kai } & \text { humeis } & \text { thelēthēte } & \text { (Ignat. Rom. 8.1) } \\
\text { want/2PL.IMPV } & \text { CONJN } & \text { and } & \text { you/NOM.PL } & \text { be-acceptable/2PL } &
\end{array}
$$

The relevant issue in the interpretation of (8) is whether the hina-clause is really an object complement to thelessate (and thus substituting innovatively for what earlier would have been an accusative plus infinitive structure) or is instead an adjunct final

\footnotetext{
${ }^{7}$ Though see (9) and footnote 9 for other possible examples.
} 
purpose or result clause that is essentially independent of thelessate. In the latter case, the use of the hina-clause need not be innovative but could simply be a continuation of the Classical (and Hellenistic) Greek use of finite purpose or result clauses. Sophocles (1914: s.v.) seems to take this sentence in the former interpretation, since he cites it without any punctuation separating thelésate and hina; for him, the translation would be 'You might want yourselves also to be acceptable' (literally: 'You might want that and you be acceptable'). For Lake (1970: 237), however, the sentence is cited with a comma (presumably an editorial addition) separating thelessate and hina; and the translation is 'Desire it [i.e. to live after the manner of men], in order that you also may be desired'. Deciding between these two interpretations is difficult, and it may well be that both are possible. Other parallel sentences are equally open to both types of interpretation; for instance, (9), also from Ignatius's Epistle to the Romans (3.1), shows how hard it can be to decide for certain:

$\begin{array}{lllllll}\text { monon } & \text { moi } & \text { dunamin } & \text { aiteisthe } & \text { esōthen } & \text { te kai } \\ \text { only } & \text { me/DAT } & \text { strength/ACC } & \text { pray/2PL.IMPV } & \text { inside } & \text { and and }\end{array}$

exōthen, hina mē monon legō

outside CONJN not only say/1SG

alla kai thelō, hina mē monon legōmai Khristianos

but and want/1SG CONJN not only be-called/1SG Christian/NOM

Lake (op. cit., 229) translates this passage as 'Only pray for me for strength, both inward and outward, that I may not merely speak, but also have the will, that I may not only be called a Christian (but may also be found to be one)', apparently taking thelō, hina mē monon legōmai as having an adjunct result hina-clause, and thelō in an absolute sense of 'have the will (to do something)'. However, Foy (1886: 159) cites (9) as the earliest case where there is identity between a main clause subject and the subject of a finite complement clause, so that an interpretation of the hina-clause as the complement of thelo meaning simply 'want, be willing' seems quite possible also. ${ }^{9}$

${ }^{8}$ I say "would be" since Sophocles does not translate this example; rather Sophocles cites it as an instance where thelèthēte means 'be acceptable', and the example appears in the lemma for thelo under the general heading of "with hina, where the classical language uses the infinitive", suggesting he indeed does take this example as an instance of the innovative finite replacement for the earlier infinitive.

${ }^{9}$ Interestingly, Foy cites this example with hopōs rather than hina as the subordinating conjunction, the form also for this example in the edition of Migne (1894: 806), so Lake may have "normalized" the syntax to hina. This does not alter the syntax of the example, for it simply means that some writers used a different conjunction, one that introduced finite complements to other verbs in Classical Greek (e.g. see below regarding peiraō in Classical Greek). Foy also cites an example from the Apocrypha, specifically the Gospel of Nicodemus (also known as Acta Pilati, the same text that is the source of (6b)), of a like-subject finite complement to thelo introduced by hina:

$$
\begin{array}{lllllll}
\text { i. } & \text { ephē } & \text { touto } & \text { thelōn } & \text { hina } & \text { se } & \text { harpasēi } \\
& \text { said/3SG } & \text { this/ACC } & \text { wanting/PPL } & \text { CONJN } & \text { you/ACC } & \text { seize/3SG }
\end{array}
$$


To a certain extent, with regard to developing an argument that pro-Drop is involved in the absence of subjects of finite clauses, the exact interpretation of (8) and (9) may not matter. In either case, one could argue that such subordinate clauses without an overt subject cannot have a PRO subject.

Assuming for the moment that Sophocles' interpretation of the hina-clause in (8) is correct and that it is a complement rather than a purpose or result clause adjunct, then the argument for the operation of pro-Drop in the complement of finite control structures is that the conditions under which the controlled complement subject appears overtly in (8) are exactly those that are predicted in an account that invokes pro-Drop in the subordinate clause. In particular, the subordinate clause subject in (8) is supported by the emphasizing element kai, here meaning 'also'; thus its appearance in (8) is exactly parallel to the appearance of the main clause subject in (6a), kai humeis thelete ..., which similarly was emphasized with kai. Such is to be expected if pro-Drop is responsible for absence of the lower clause subject, for emphatic subjects would not be suppressed by pro-Drop. The appearance of a subject in the finite complement when it is emphatic, as in (8), but not otherwise, as in (6b), therefore confirms the operation of pro-Drop in sentences with a finite complement verb. ${ }^{10}$

Even if, on the other hand, the hina-clause in (8) is not a complement in the usual sense but rather a purpose or result adjunct clause, the argument about pro-Drop can still go through, under the assumption that a missing subject in a purpose clause was at some stage of Greek to be represented by PRO. Although finite purpose clauses were possible in Classical Greek and in Hellenistic Greek, so too were infinitives of purpose; it is not clear if hina (hopōs)-clauses after thelō can be construed as replacements for infinitives of purpose, but if they can, and if the missing subject with infinitival purpose clauses is a PRO (as assumed above for (3)), then the same question about a missing subject in (9) can be asked, namely whether it is PRO or pro. The evidence of (8), with its emphatic subordinate subject in just the place where a pro-Drop account would predict, thus is consistent with the assumption of pro as the missing subject, regardless of whether the clause is a purpose clause (that is, an adjunct) or a real complement clause.

In this account, therefore, not only is the need eliminated for positing PRO in the innovative structures with finite complements, but also crucial reference is made to the meaning of the complement to thelo as like-subject or unlike-subject, and thus to the meaning of the overall combination of thelo with its complement. These developments suggest, therefore, that the approach in which control is viewed as being tied to lexical semantics may well have some validity.

'He said this, wanting to seize you' (literally: '[...]wanting that he seize you.')

Given that there are several possible Hellenistic examples of like-subject complements with thelo, and that this type eventually develops, it seems justified to accept this as a legitimate Hellenistic syntagm.

${ }^{10}$ The fact that a case-marked (here, nominative) pronoun occurs in the subordinate clause of (8) offers additional support for the claim that what is involved in finite control situations is pro and not PRO in frameworks in which PRO is banned from case-marked positions (e.g. as in Bouchard 1984 or Varlokosta \& Hornstein 1993, the latter specifically on Modern Greek) while pro can only occur in such positions (as in Rizzi 1986). See Philippaki-Warburton (1995), and Philippaki-Warburton \& Catsimali (1996, 1997, 1999) for discussion of various proposals concerning pro and PRO in Modern Greek finite complements (with some reference as well to infinitival structures in earlier stages of Greek), and the claim that finite control structures involve pro and not PRO. 
The relevance of lexical semantics to an understanding of control emerges also when one looks at the classes of predicates that in Hellenistic Greek were most resistant to encroachment of the infinitive by a hina clause. These include verbs and adjectives whose basic semantics would seem to require like-subject control $^{11}$ in that an unlike-subject complement with them is difficult to even conceive of, such as arkhomai 'begin', dunamai 'can, be able, have the power to' (and its later synonym, euporō 'be able', via a semantic shift from the Hellenistic meaning of 'have plenty, be well off, have (financial) ability'), dunatos '(be) capable; (be) in a position to', and opheilō 'be obligated; ought'. The relative lateness of their giving way to finite complementation is shown by the fact that is essentially just these verbs that still allow an infinitive optionally in Medieval Greek, as argued in Joseph (1978/1990: 31). Thus the collection of those predicates which hold out the longest in the face of the onslaught, as it were, of finite complementation is not a random assortment of verbs and adjectives, sprinkled through the lexicon willy-nilly, but rather gives evidence of some semantic coherence in that they obligatorily impose a like-subject condition on their complement clauses.

Further evidence of the importance of lexical semantics to control comes from the situation with the verb 'try' in Hellenistic Greek and later. In the Greek New Testament, the verbs for 'try', mostly peirazo $\bar{O}^{12}$ but also peiraomai, are wellbehaved with respect to control in that all examples of a complement clause involve an infinitive, and with no overt subject, the empty complement subject is always interpreted as like-subject, under control from the main-clause subject, as in (10): ${ }^{13}$
epeirazon eis
tēn
Bithunian
poreuthēnai
(Acts 16:7)

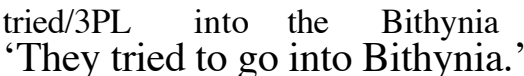

Under the assumptions made above about the representation of control structures within GB theory, (10) would have PRO as the subject of the infinitive:

\section{(11) [epeirazon [ PRO eis tēn Bithunian poreuthēnai].}

There is one example of peirazo, as pointed out in footnote 13 , in which an overt subject, marked with the accusative case, occurs with the infinitive and is not interpreted under control from the main clause subject, as given in (12):

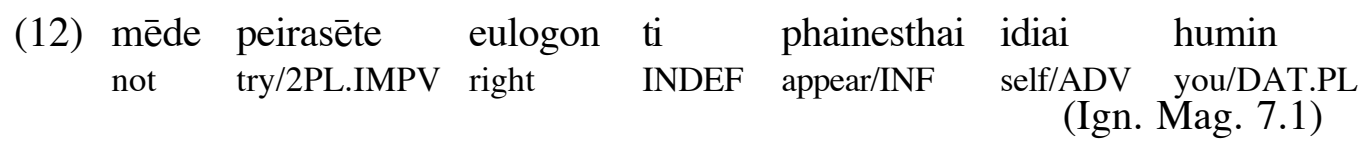

\footnotetext{
${ }^{11}$ It may well be that some of these verbs are actual Subject Raising verbs and not control verbs in the strict sense or admit both types of structures (as has been argued for begin in English, for instance, by Perlmutter 1970). The resistance of some of these predicates to the innovative use of the infinitive is noted by Jannaris (1897: §2090ff.).

${ }^{12}$ This verb also means 'try' in the sense of to test or tempt someone.

${ }^{13}$ This is leaving aside for the moment one example, discussed in more detail below, in which peirazo occurs not just with an infinitive, but with an accusative subject - different from the subject of peiraz $\bar{o}-$ for that infinitive. Still, it is significant that all six examples of peirazo with a complement clause and no overt subject to be found in the Hellenistic Greek corpus upon which Arndt \& Gingrich (1957) is based, as well as the one instance of peiraomai in the New Testament, show no alternative complement types.
} 
This sentence is translated by Lake (1975: 203) as 'Do not attempt to make anything appear right for you by yourselves'. The significance of this example is discussed further below.

The verb in Modern Greek that corresponds in meaning to peirazō is prospa $\theta$, which does not continue earlier peirazō, but instead derives from earlier prospathe $\bar{o}$ 'feel passionate love for'; there has thus been a shift in the meaning of prospatheo to assume the complement-taking sense of 'try', as well as the encroachment on and eventual replacement of earlier peirazō in this meaning. ${ }^{14}$ Still, examining Modern Greek prospa $\theta o$ alongside peirazō proves interesting for their properties support the view that control is a matter of lexical semantics, and prospa $\theta o$ provides further evidence against positing a PRO missing subject.

In particular, as illustrated in (13), prospató at first appears to exhibit syntactic control properties somewhat like those seen in Hellenistic sentences such as (6b) or (9), with a missing overt subject in the complement clause that is interpreted as identical with the main clause subject:

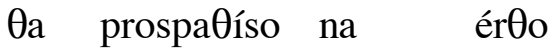

$$
\begin{aligned}
& \text { FUT try/1SG SUBJNC come/1SG } \\
& \text { 'I will try to come.' }
\end{aligned}
$$

However, as (8) indicated for finite complements in Hellenistic Greek, a subject can be present in the complement clause imparting particular emphasis on the subject, as in (14), suggesting that the absence of the subject in (13) is a matter of pro-Drop and not a special type of control phenomenon from the syntactic standpoint:

$$
\begin{array}{llll}
\theta \text { a prospaӨíso na } & \text { érӨo } & \text { eró } \\
\text { FUT try/1SG } & \text { SUBJNC } & \text { come/1SG } & \text { I/NOM } \\
\text { 'I will try to come.' } & &
\end{array}
$$

Moreover, and this is where Modern Greek 'try' deviates from Hellenistic Greek 'try', prospaӨó can have finite complement with a subject that is different from that of the main verb:

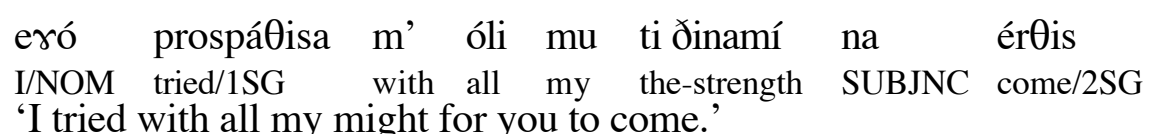

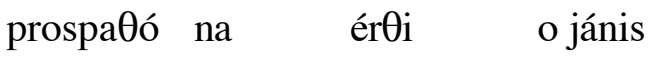

$$
\begin{aligned}
& \text { try/1SG SUBJNC come/3SG the-John/NOM } \\
& \text { 'I try for John to come.' }
\end{aligned}
$$

Thus, prospa $\theta$ ó in Modern Greek is more like Hellenistic Greek thelō 'want' than like Hellenistic peirazo 'try' in that it can take finite complements, whether like-subject or unlike-subject. In terms of the meaning of the complements, as opposed to their form,

\footnotetext{
${ }^{14}$ This verb continues in Modern Greek with the primary meaning of 'tease, annoy', though the related deverbal noun pirazmos does mean 'temptation'.
} 
the unlike-subject example with peirazo, (12) above, shows that both Hellenistic peirazō and Modern prospa $\theta$ ó do not impose obligatory control over the subject of their complements, apparently like thelo. There is a difference, however, between peirazō/prospäó and thelō. The verb thelo has essentially the same meaning with both like- and unlike-subject complement types, but such is not the case with

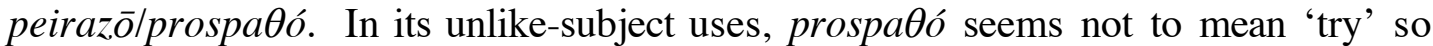
much as something like 'facilitate' or 'cause to bring about; aid in bringing about'; thus, (15b) really means 'I facilitate it so (i.e. try to make it come about) that John comes' whereas a like-subject use such as (10) means rather 'I make the attempt myself to bring it about that I come'. In a sense, then, like-subject peirazō/prospa $\theta$ ó and unlike-subject peirazō/prospa $\theta$ ó should be treated as essentially two different, but homophonous, lexical items, each with its own particular meaning. ${ }^{16}$ The Modern Greek counterpart to Hellenistic Greek peirazō in its use with control of the subject position associated with its complement-clause infinitive is like-subject prospa $\theta$, which could legitimately be thought of as a control verb itself, just not one that has PRO as subject of its complement clause. Such a verb would thus show control into a finite clause, though the syntactic mechanism for representing that control would not be PRO but rather pro, and the semantics of the main verb would guarantee that pro is always appropriately interpreted as being under control from the main clause subject. Like-subject peirazō/prospäó, therefore, having the meaning 'try', can be thought of as obligatory control verbs, whereas unlike-subject peirazō/prospa $\theta$ ó would have the meaning 'aid in bringing about, facilitate' or the like, and would not be a control verb. In neither case would PRO need to be invoked; the missing subject could be a matter either of pro-Drop, for a finite complement, or derivable from the meaning of the main verb, for a pro subject. ${ }^{17}$

The upshot of this examination of 'try', as in the other cases discussed in this section, is that PRO can be dispensed with for finite complements in favor of an approach to control that emphasizes the role played by lexical semantics. ${ }^{18}$ The

\footnotetext{
${ }^{15}$ In this way, 'try' is somewhat like the English verb hope, which with a like-complement-subject (e.g. I hope to win) has an inner-directed meaning but with an unlike-complement-subject (e.g. I hope for Robin to win) has a more outer-directed meaning. I am grateful to my colleague Bob Levine for bringing this to my attention and for other helpful discussion on this matter. Perlmutter (1970) draws attention also to verbs like threaten with different meanings as in There threatened to be a riot and They threatened to resign (and ambiguity in The students threatened to take over the building).

${ }^{16}$ This is akin to the approach taken by Terzi (1992), who distinguishes two representations for Modern Greek prospa $\theta$ ó, each associated with different syntactic structures and different lexical entries: her 'try 1' (the like-subject verb) selects for a na-clause with a PRO subject, and 'try 2' (the unlikesubject verb) selects for an adjunct na-clause and has pro or lexical nominal as subject.

${ }^{17}$ PRO would presumably still be needed for like-subject instances in Hellenistic Greek, such as in (10).

${ }^{18}$ The prediction of Culicover \& Wilkins $(1986: 121$, fn. 2$)$ is worth keeping in mind here, that in a language without an infinitive, "“control' would be accomplished differently" from the device of PRO that has been developed for an infinitival language like English. Still, it has been argued by Varlokosta \& Hornstein (1993) (so also Terzi 1991, 1992) that languages like Modern Greek have PRO in (at least some) finite complement clauses (those whose main verbs require obligatory likesubject complements) in addition to pro in others. Philippaki-Warburton \& Catsimali (1999) offer an important critical review of various arguments given in support of PRO in finite complementation in Modern Greek.
} 
argumentation for Hellenistic Greek is admittedly somewhat circumstantial, in that the sort of evidence one might look to in order to directly distinguish PRO from pro, as Varlokosta \& Hornstein (1993) (among others) attempt to do for Modern Greek (see note 18), such as the possibility of split antecedents or sloppy as opposed to strict identity readings for anaphors under conditions of ellipsis, and the like, involves data not readily available for Hellenistic Greek.

However, leaving aside the cases like (5) and (6b) since they represent the constructions whose analysis is at issue here, there is evidence available for Hellenistic Greek that does suggest that an effect analogous to control into a finite clause is possible. This evidence comes from the copy-raising construction argued for by Marlett (1976) and discussed also in Joseph (1978/1990, 1992), and involves controllike effects in what might be called "derived control" structures, where there is a "derived", i.e. nonunderlying, relationship between a nominal in one clause and an anaphor in a lower clause. Thus, this construction involves "control" only in the broadest sense noted in the introduction. Still, the control-like effects in this construction show up via an overt pronominal in the complement clause, and the overtness of the pronominal means that positing an element like PRO is an unnecessary step for representing at least this type of control. An example is given in (16):

$$
\begin{array}{llllll}
\text { blepe } & \text { tēn diakonian } & \text { hēn } & \text { parelabes } & \text { en } & \text { kuriōi } \\
\text { see/IMPV } & \text { the-ministry/ACC } & \text { which/ACC } & \text { received/2SG } & \text { in } & \text { lord/DAT }
\end{array}
$$

$$
\begin{array}{lll}
\text { hina } & \text { autēn }_{\mathrm{i}} & \text { plērois } \\
\text { COMP } & \text { it/ACC } & \text { fulfill/2SG }
\end{array}
$$

'See to it that you complete the work which you have received in the Lord' (literally: 'See to the work [...]that you complete it.')

$$
\begin{aligned}
& \text { egnōn se hoti sklēros ei anthrōpos (Matt. 25:24) } \\
& \text { knew/1SG you/ACC COMP hard/NOM are/2SG man/NOM } \\
& \text { 'I knew that you are a hard man.' } \\
& \text { (literally: 'I knew you that you are a hard man.') }
\end{aligned}
$$

This construction can be said to involve control not only because there is a link between a (surface) nominal in a higher clause and one in a lower clause, but also because that link is a necessary one; that is, there are no sentences of the sort [know X [COMP NP V Y]], rather only ones in which there is a pronominal in the lower clause coreferent with the "X" of the main clause (the raised nominal).

Even with examples such as (16) under the analysis Marlett argues for, though, there is no necessity for positing PRO. In the case of nonsubjects, as in (16a), an overt coreferent pronominal element is always present, for Greek does not have a process by which nonsubject definite pronominals can generally be suppressed. When lower clause subjects are the "target" of the derived control, as in (16b), just as is argued above regarding (6b) and similar sentences, it can again be the case that proDrop is at work. Relevant here is the fact that, as in (17), an overt subject pronoun can occur in the complement clause in this construction, ${ }^{19}$ under conditions of emphasis, just as would be expected in a pro-Drop analysis: ${ }^{20}$

\footnotetext{
19 And, as noted above in footnote 10 with regard to (8), the overtly case-marked (nominative) subordinate clause subject in (17) speaks in favor of the pro analysis and against the PRO analysis.

${ }^{20}$ The emphasis is evident in some available translations; the Gideons International translation, for instance, has "Then they knew that it was he who sat ...".
} 


$\begin{array}{lllllc}\text { epeginōsken } & \text { de } & \text { auton } & \text { hoti } & \text { houtos } & \text { ēn } \\ \text { knew/3PL } & \text { and } & \text { him/ACC } & \text { COMP } & \text { this/NOM.MASC } & \text { was/3SG }\end{array}$

ho kathémenos (Acts 3:10)

the-sitting/NOM.MASC.SG

'And they knew him to be the one sitting ....'

(literally: 'They knew him that he was the one sitting[....]')

Thus in the one Hellenistic clear case of non-freely interpreted pronominals in a finite clause - that is, in control structures in the broadest sense - there is no need to invoke PRO. By extension, therefore, in cases like (6b), there would similarly be no reason to think of anything other than pro as the representation of the missing subject in the complement clause. Interpretation of pro as controlled by the main clause subject would be derivable from the lexical semantics of the main clause verb; a predicate meaning 'try' or 'capable, or the like, would exert obligatory (like-subject) control, whereas a verb meaning 'want' would allow complement clauses with controlled subjects or with freely selected subjects.

\section{Conclusion - Diachronic Syntax and Control}

What all these historical developments with control in Hellenistic Greek point to, therefore, especially with regard to the innovative finite complement structures that emerge in later Hellenistic Greek and continue to spread at the expense of infinitival complements in Medieval Greek and on into Modern Greek, is that control is an inherently semantic notion, a phenomenon that is more a matter of lexical semantics than of syntax per se.

By way of conclusion, since the potentially interesting aspects of control structures in Greek seem to be the developments noted here that were emerging towards the end of the Hellenistic period, continuing on into post-Hellenistic Greek, it is interesting to consider what this historical evidence may mean for the study of historical syntax and syntactic change, in the Greek context and even more generally.

In studying the historical syntax of a language, researchers are often in the position of having to reconstruct what the starting point for a particular construction was or to make educated guesses in order to fill in gaps in the documentary record. However, those interested in tracing developments in the historical syntax of the Greek language are fortunate in having not only the rich attestation of Classical Greek from roughly the 8th through the 4th centuries $\mathrm{BC}^{21}$ but also the abundant evidence of contemporary Modern Greek serving, respectively, as approximations to the beginning point and the endpoint against which one can judge whether changes have occurred. Moreover, there is the ample documentation of intermediate stages, including Hellenistic Greek and the considerable, but still relatively underexamined, material of Byzantine and Medieval Greek, covering roughly the 4th to the 17 th centuries AD, that allow one to trace the steps by which the unfolding of syntactic developments took place. Comparisons that can be made across the history of Greek fall into several types.

In one type of comparison, there is agreement between Classical and Modern Greek with regard to some structure, and moreover Hellenistic Greek shows the same structure. In such a case, therefore, there is continuity through these various stages of Greek. This situation is found, for instance, in some very general aspects of Greek

\footnotetext{
${ }^{21}$ Thus for the purposes of this discussion here, "Classical" can be taken to include Homeric Greek, despite the fact that Homer's language is in many respects significantly more archaic than Classical Attic Greek.
} 
morphosyntax, such as the consistent use across the centuries of the nominative case to mark surface subjects of finite verbs or the necessity for agreement between an adjective and a noun it modifies, as well as in lexically quite specific ones such as the occurrence of accusative case marking, and only accusative case, on the object of the preposition eis 'to, into' at all stages of Greek. ${ }^{22}$ With regard to more fully syntactic phenomena, the pro-Drop phenomenon mentioned above for Hellenistic and Modern Greek can be cited here, for it is found in all stages of Greek, ${ }^{23}$ and has thus shown stability throughout the history of the language.

In a second type of comparison, Hellenistic Greek, which is a chronological way station between Classical Greek and Modern Greek, gives evidence of being a structural way station as well. That is, in such a case, evidence of a change between Classical and Modern Greek arrived at by a simple static comparison of relevant structures in these two stages of the language is confirmed by the appearance in Hellenistic Greek of transitional structures or of transitional stages, often with an innovative structure being seen for the first time in the Hellenistic period. An example is the loss of the dative case, for this case is robust in Ancient Greek, is absent altogether from Modern Greek, and is beginning in Hellenistic Greek to be encroached upon by prepositional phrases occurring where earlier Greek used a simple dative nominal. Similarly, as noted in section 2, with the replacement of the infinitive by finite verbal forms in complementation, a verbal category that was well-represented and much used in Ancient Greek, but totally absent from Modern Greek, can be seen in Hellenistic Greek to show signs of weakening, giving way to finite complementation; a sentence such as (7) above, where the older infinitival complementation and the innovative finite complementation are conjoined, governed by the same verb, is powerful evidence of Hellenistic Greek as a transitional stage in the retreat of the infinitive.

These two patterns of comparison involving different stages of Greek are by far the most commonly instantiated, and represent the typical way in which stability is manifested and the typical way in which change emerges across the history of Greek. The case of control structures with 'try', however, is of particular interest for it turns out that certain aspects of their development seem not to fit into these usual patterns. From a methodological standpoint, such a case potentially would invalidate the use of Hellenistic Greek syntax as a checkpoint in the historical development of Greek syntax.

As shown in the previous section, 'try' in Hellenistic Greek, as represented by the verbs peirazo and peiraomai, is attested only with infinitival complements, and has a like-subject reading in most of its occurrences, with a somewhat different main verb meaning, on the order of 'aid in bringing about, facilitate', in its unlike-subject use; in Modern Greek, on the other hand, the corresponding verb prospa $\theta$ ó occurs only with finite complementation, the norm across all of Modern Greek, though it too can mean both 'try' in a like-subject sense or 'aid in bringing about' in an unlike-subject sense. Thus it would appear that there has been a change between Hellenistic Greek and

\footnotetext{
${ }^{22}$ This includes, of course, later morphologically natural or phonologically regular developments from eis, such as Medieval Greek eisé (phonetically [isé]) or Modern Greek $s(e)$; the specialized, and presumably elliptical, use of Modern Greek $s(e)$ with the genitive of a personal name to mean 'at someone's house' (e.g. s tu Jáni 'at John's (house)', literally "at of-the of-John”) is excluded here.

${ }^{23}$ One fairly recent construction found in Modern Greek, involving the preferred use of innovative third person weak nominative pronouns with the presentational deictic predicate ná 'here is/are!' and their obligatory use with the locative interrogative predicate pún 'where is/are?', challenges the characterization of the modern language as an "ordinary" pro-Drop language; see Joseph (1994) for some discussion.
} 
Modern Greek regarding the complementation possibilities for both senses of the lexeme meaning 'try; facilitate'. At this point, this situation is quite parallel to others noted above, where an innovation has taken place between Hellenistic and Modern Greek.

However, the situation with 'try' in Classical Greek raises a question concerning the source and the chronology of the apparent innovation. In particular, even though 'try' in Classical Greek could take an infinitive as complement, with an empty subject interpreted as identical with the main-clause subject, there are examples in Classical Greek of a finite complement with peiráo 'try', as in (18a), and moreover, instances in which that finite complement has a different subject from the main clause, as in (18b):

$$
\begin{aligned}
& \text { peira hopōs ken de sēn patrida gaian hikēai (Odys.4.545) } \\
& \text { try/2SG.IMPV COMP MOD now your-home-land/ACC come/2SG.SUBJNC } \\
& \text { 'Try to come back to your homeland.' } \\
& \text { (literally: 'Try that (you) come back[...]') }
\end{aligned}
$$

peiran d' hōs ke trōes .... / $/$ arksōsi
try/INF but COMP MOD Trojans/NOM
'[...] to try to make it so that the Trojans are first/...]"

'[...] to try to make it so that the Trojans are first[...]'

As the translation, following Lattimore (1951), indicates for (18b), the unlike-subject example seems to involve lexical semantics for the main verb somewhat akin to the 'facilitate' reading given above for unlike-subject prospäó in Modern Greek. Thus there is actually diachronic stability between Classical Greek and Modern Greek with regard to the possibility of finite complementation with 'try', and in the particular lexical semantics associated in unlike-subject complementation with the verb that otherwise means 'try'. However, Hellenistic Greek fits in here as being like Classical and Modern Greek only on the latter count, not on the possibility of finite complementation with the 'try'-verb. Thus in this regard, there is actually stability between an early stage (Classical Greek) and the present-day, but apparently no continuity through Hellenistic Greek, counter to the more usual patterns discussed above and thus casting some doubt on the view of Hellenistic Greek as transitional between Ancient and Modern Greek.

There are several possible solutions to this problematic situation, however. First of all, it may simply be that all that is at issue here is an attestation problem, and that Hellenistic Greek actually did allow a Modern and Classical sort of finite complement structure with 'try' but there are simply no attested instances; attestation is, after all, a matter of chance, and thus there is no guarantee that a given feature has to be exemplified at all stages of any language one might examine. ${ }^{24}$ Still, relying on such reasoning, however justifiable it may be, is itself somewhat problematic since it is not falsifiable. Moreover, it has the appearance of being a mere dodge, a convenience rather than a real explanation.

Second, it could be the case that two different changes occurred, one between Classical and Hellenistic Greek restricting the range of complement types that peira $\bar{o}$ 'try' could occur in, and another between Hellenistic Greek and Modern Greek expanding this range (once again). This latter view is supported by the fact already pointed out that finite complementation was in the process of replacing nonfinite complementation in Hellenistic Greek, so that the Modern Greek complement-type

\footnotetext{
${ }^{24} \mathrm{Of}$ course, problems associated with the vagaries of attestation are not just an issue for historical linguistics; they arise as well in the study of language acquisition, among other areas of inquiry.
} 
must have become available with the verbs with these meanings at some point between the Hellenistic and Modern periods. Moreover, prospaӨó does not directly continue earlier peiráō but rather represents a lexical replacement and shift of meaning. Thus, if it is assumed that the range of complementation possibilities with a verb is to some extent a matter of lexical specification, ${ }^{25}$ then one lexical change with 'try' is needed anyway; positing another change in lexically specified complementation possibilities is therefore not a difficult assumption to make. ${ }^{26}$ Under this account, the lack of continuity may just be a mirage, as it were, reached by making a broad comparison of three different stages of Greek rather than a more graduated step-wise comparison; looked at pairwise, the comparisons between Classical and Hellenistic Greek and between Hellenistic and Modern Greek fit expected patterns. The importance of the lexicon for this aspect of control structures would be consistent with the general view espoused here in which control is tied to an aspect of the lexicon, i.e. a verb's lexical semantics, and not to some aspect of a verbal complement's abstract syntactic structure.

Earlier stages of Greek, and the transitions between them, thus have much to offer to the debate concerning the nature of control, pointing towards the lexically-based accounts of Comrie (1985), Farkas (1988), Ladusaw \& Dowty (1988), and Culicover \& Jackendoff (2001), among others. At the same time, though, it must be admitted that much is indeterminate about the specifics of control in earlier stages of Greek and the changes that these constructions underwent, and will probably always remain so, given limitations inherent in historical syntactic investigations regarding access to crucial data and similar issues.

Thus, besides the value of the account given here for the proper analysis of control, there are methodological lessons to be learned as well concerning the practice of historical syntax. Moreover, as far as the history of Greek itself is concerned, there is one methodological matter of paramount importance: the issue of stability with control and 'try' in all stages of Greek has an impact on how Hellenistic Greek is to be viewed, vis-à-vis the other stages of the language. But a resolution to even this issue depends on the availability of suitable data, the most crucial aspect, perhaps, to any linguistic investigation.

\footnotetext{
${ }^{25}$ Admittedly, as noted above, there are some semantic generalizations to be made as to which verbs hold out the longest with infinitival complements, there are cases of synonymous verbs that behave differently with regard to finite versus nonfinite complementation. For instance, ea⿳亠口冋 'allow' takes only an infinitive in the New Testament whereas aphienai, with the same meaning, can occur with a finite hina-clause as complement.

${ }^{26}$ Although the retreat of the infinitive, giving way to finite complementation, shows a steady overall movement in the direction of the finite forms, if charted on a century-by-century basis (see Joseph 1978/1990: Chapter 2, 1983: Chapter 3, for some relevant discussion), there were occasional instances of the "rejuvenation" of the infinitive. Such is the case, for example, from a functional standpoint, with the innovative Circumstantial Infinitive construction that arose and flourished in the $12^{\text {th }}$ to $14^{\text {th }}$ centuries in Medieval Greek (as discussed in Joseph 1978/1990, 1983, 1992, 1994, 2001, as well as Joseph 2000). Therefore it is not at all unreasonable to posit that one verb might have innovatively adopted infinitive-only complementation on the way into Hellenistic Greek even in the face of a more general infinitive-replacement process that was gaining "steam", so to speak, in that same era. Indeed, at least one construction-specific shift to greater infinitival usage did take place in the Hellenistic period, in the infinitive of purpose following verbs of motion; as noted by BlassDebrunner (1961: §388), this usage is expanded in Hellenistic Greek from its range of applicability in Classical Greek.
} 


\section{References}

Arndt, William F. \& F. Wilbur Gingrich. 1957. A Greek-English lexicon of the New Testament and other early Christian literature. Chicago: The University of Chicago Press.

Blass, Friedrich \& Albert Debrunner. 1961. A Greek grammar of the New Testament and other early Christian literature (translated and revised by Robert W. Funk). Chicago: The University of Chicago Press.

Bouchard, Dénis. 1984. On the content of empty categories. Dordrecht: Foris.

Chaski, Carole E. 1988. GB, GPSG and the separation of agreement and case. Papers from the $24^{\text {th }}$ regional meeting of the Chicago Linguistic Society: Parasession on agreement in grammatical theory, 28-40.

Chomsky, Noam. 1981. Lectures on government and binding. Dordrecht: Foris.

Comrie, Bernard. 1985 [1988]. Reflections on subject and object control. Journal of Semantics 4.48-65.

Culicover, Peter W. \& Ray Jackendoff. 2001. Control is not movement. Linguistic Inquiry 32.493-512.

Culicover, Peter \& Wendy Wilkins. 1986. Control, PRO, and the projection principle. Language 62.120-153.

Farkas, Donka. 1988. On obligatory control. Linguistics and Philosophy 11.27-58.

Foy, Karl. 1886. Ke palin to zitima ton aparemfatikon tipon [Once again the Question of Infinitival Forms]. Imerolojion tis anatolis politiografikon, filolojikon ke epistimonikon tu etus 1887, 148-169.

Hornstein, Norbert. 1999. Movement and control. Linguistic Inquiry 30.69-96.

Jannaris, Antonius N. 1897. An historical Greek grammar. London: MacMillan and Co. (reprinted 1987, Georg Olms Verlag, Hildesheim).

Joseph, Brian D. 1978/1990. Morphology and universals in syntactic change: Evidence from medieval and modern Greek. Harvard University Ph.D. Dissertation, printed and distributed by Indiana University Linguistics Club. [Updated and augmented version published (1990) in Outstanding Dissertations in Linguistics series, New York: Garland Publishing Inc.]

- - - . 1983. The synchrony and diachrony of the Balkan infinitive: a study in areal, general, and historical linguistics. (Cambridge Studies in Linguistics, Supplementary Volume 1). Cambridge: Cambridge University Press.

- - _ . 1992. Diachronic Perspectives on Control. Control and grammar, ed. by Richard K. Larson, Sabine Iatridou, Utpal Lahiri, and James Higginbotham, 195234. Dordrecht: Kluwer Academic.

- - - . 1994. On weak subjects and pro-drop in Greek". Themes in Greek linguistics (Papers from the First International Conference on Greek Linguistics, Reading, September 1993), ed. by Irene Philippaki-Warburton, Katerina Nicolaidis, and Maria Sifianou, 21-32. Amsterdam: John Benjamins.

- - - . 2000. Textual authenticity: Evidence from medieval Greek. Textual parameters in ancient languages, ed. by Susan Herring, Piet van Reenen, and Lene Schøsler, 309-329. Amsterdam: John Benjamins.

Koster, Jan. 1984. On binding and control". Linguistic Inquiry 15.417-457.

Ladusaw, William \& David Dowty. 1988. Toward a non-grammatical account of thematic roles. Thematic relations (Syntax and Semantics 21), ed. by Wendy Wilkins, 62-72. New York: Academic Press.

Lake, Kirsopp. 1970; 1975. The Apostolic Fathers; with an English Translation (Loeb Classical Library, 28). Cambridge: Harvard University Press [Volume 1 (1975); Volume 2 (1970)]. 
Larson, Richard K., Sabine Iatridou, Utpal Lahiri, and James Higginbotham. Eds. 1992. Control and grammar. Dordrecht: Kluwer Academic.

Lattimore, Richmond. 1951. The Iliad of Homer. Chicago: The University of Chicago Press.

Marlett, Stephen. 1976. Copy raising in Koine Greek. M.A. Thesis, University of North Dakota.

Migne, Jean-P. 1894. Patrologiae Cursus Completus. Series Graeca (Patrologiae Graecae, V). Paris: Garnier Bros.

Miller, D. Gary. 1974. On the history of infinitive complementation in Latin and Greek". Journal of Indo-European Studies 2.223-246.

Perlmutter, David M. 1970. The two verbs begin. Readings in English transformational grammar, ed. by Roderick A. Jacobs and Peter S. Rosenbaum, 107-119. Waltham, MA: Ginn and Company.

Philippaki-Warburton, Irene. 1995. On control in modern Greek”. Reading Working Papers in Linguistics 2, 143-158.

Philippaki-Warburton, Irene \& Catsimali, Georgia. 1990. 'Accusativus cum infinitivo' sta Arhea Elinika ['Accusativus cum Infinitivo' in Ancient Greek]. Studies in Greek Linguistics 10 (Proceedings of the $10^{\text {th }}$ annual meeting of the Department of Linguistics, Faculty of Philosophy, Aristotle University of Thessaloniki), 89-108.

- - - . 1996. Domes elenxu sta Nea Elinika [Control constructions in Modern Greek]. Studies in Greek Linguistics 16 (Proceedings of the $16^{\text {th }}$ annual meeting of the Department of Linguistics, Faculty of Philosophy, Aristotle University of Thessaloniki), 693-704.

- - - . 1997. Control in Ancient Greek. Greek linguistics 1995. Proceedings of the 2nd international conference on Greek linguistics. Vol. II, ed. by G. Drachman, A. Malikouti-Drachman, J. Fykias and C. Klid, 577-588. Graz: W. Neubauer Verlag GmbH.

- - - . 1999. On control in modern Greek. Studies in Greek syntax, ed. by Artemis Alexiadou, Geoffrey Horrocks and Melita Stavrou, 153-168. Dordrecht: Kluwer Academic Publishers.

Rizzi, Luigi. 1986. Null objects in Italian and the theory of pro. Linguistic Inquiry 17.501-557.

Sophocles, E. A. 1914. Greek lexicon of the Roman and Byzantine periods. Cambridge: Harvard University Press.

Terzi, Arhonto. 1991. PRO and obviation in modern Greek subjunctives. Proceedings of the West Coast Conference on Formal Linguistics 10.471-482.

Terzi, Arhonto. 1992. PRO in finite clauses: a study of the inflectional heads of the Balkan languages. CUNY Graduate Center Ph.D. Dissertation.

Varlokosta, Spyridoula \& Norbert Hornstein. 1993. Control in modern Greek. Proceedings of the North East Linguistic Society 23, volume 2, ed. by Amy J. Schafer, 527-521. Amherst: GLSA, Department of Linguistics, University of Massachusetts.

Author's contact information:

Brian Joseph

bjoseph@ling.ohio-state.edu

Department of Linguistics

222 Oxley Hall

The Ohio State University

Columbus, Ohio USA 43210-1298 